\title{
IMPORTANCE OF REMOTE SENSING FOR THE STUDY OF SPATIAL DYNAMICS OF ESTUARINE NEUSTON FROM SOUTHERN CHILE
}

\author{
Juan I. Cañete ${ }^{1 *}$, Carlos Cárdenas ${ }^{2}$, Máximo Frangópulos² ${ }^{2}$ Ximena Aguilar² \& Javier Díaz-Ochoa ${ }^{1}$ \\ 1 Dept. Ciencias y Recursos Naturales, Facultad de Ciencias, Universidad de Magallanes, Punta Arenas, Chile \\ 2 Centro de Investigación GAIA Antártica, Universidad de Magallanes, Punta Arenas, Chile \\ ivan.canete@umag.cl*
}

KEY WORDS: LAGIRS, Neuston, Magellan Strait, Wake-island effect, Meso-scale studies, Chlorophyll a, Microsetella.

\begin{abstract}
:
Zooplankton aggregation, hydrographic and remote sensing data were employed to relate the spatial dynamics of neustonic communities with chlorophyll a (Chl $a$ ) and suspended organic matter (SOM) at a spatial mesoscale (10 to $1000 \mathrm{~km})$ in the southern Chilean fjords system along Magellan Strait, Chile (CIMAR 16: October/November 2010 and CIMAR 25; September/October 2019) in order to identify oceanographic process producing aggregation of neuston. Preliminary evidence of CIMAR 25 shows significant concentrations of Chl $a$ and SOM around Dawson Island (DI), Magellan Strait. During CIMAR 16 important aggregation of specific neustonic taxa (copepodites of Microsetella rosea, larvae of the polychaete Polygordius $s p$ and cyphonautes of the bryozoan Membranipora isabelleana) was observed around DI, Magellan Strait. Satelital images in the area of CIMAR 16 provide evidence of important aggregation of chlorophyll $a / \mathrm{SOM}$ around DI. CIMAR Cimar 25 showed that the Chl $a$ and SOM aggregation around DI is recurrent and could to explain the high concentration of neuston around this island to spite of mesotrophic conditions. Remote sensing in this study area provides a tool to understanding oceanographic and topographic factors that potentially regulate the abundance and spatial distribution of surface zooplankton to spatial meso-scale along Magellan Strait.
\end{abstract}

\section{INTRODUCTION}

The biodiversity levels and densities of neustonic organisms their spatial and temporal variation, their roles in sustaining biogeochemical cycling and atmosphere-ocean exchange processes, as well as a nutritional source for important trophic networks in significant areas of the oceans, all remain unknown (Hardy, 2005). The present study describes the structure and biodiversity of neustonic communities in Southern Chile, which includes an extended estuarine environment with roughly $1,500 \mathrm{~km}$ of fragmented coastline. This area is characterized by the largest fjord systems in the world where salty Subantarctic Surface Water and Modified Subantarctic Waters mix with freshwater, generating sharp vertical and horizontal salinity gradients. These salinity gradients create strong biological consequences, including a stratification effect caused by buoyancy, which is a key regulator of primary production and biomass, a limitation on the depth of turbulent mixing, keeping algal cells within the photic zone; the concentration of an important fraction of organic matter and planktonic communities; and a change in the abundance and spatial distribution of the neuston (Dávila et al., 2002; Silva, Palma, 2008; Pantoja et al., 2011; Iriarte et al., 2014; Cañete et al., 2016).

The neuston represents the atmospheric-oceanic interface which can be thought of as the ocean's skin, given that it is only a few centimeters thick (Hardy, 1991), and covers $71 \%$ of the planet's surface. The physical processes occurring there are critical to the global conservation of biogeochemical cycles, but latitudinal differences in the neuston's environmental functions, such as fragmentation and transport of organic matter to greater depths, are not well understood (Zaitsev, 2005; Koski et al., 2007).

In temperate zones, the neuston plays an important trophic role as a food source for meso- and macro-zooplankton and is a key component in the production of "marine snow" and the vertical transport of organic material from the ocean surface to greater depths (Zaitsev, 2005; Hays et al., 2005). Mesozooplankton living here are crucial to the sustenance and survival of important fisheries (Zaitsev, 2005). For these reasons, it would be very useful to understand how the neuston is influenced by environmental and oceanographic factors, including temperature, solar radiation, salinity, and acidification (Hardy, 1991; Zaitzev, 2005) and are important themes in oceanographic research that are associated with climatic warming and oceanographic change in sub-polar marine ecosystems (Zaitsev, 2005, Cañete et al., 2019).

The aim of this study is the integration of zooplankton, hydrographic (sea surface temperature, salinity and dissolved oxygen) and remote sensing analysis (Chlorophyll a) to relate the spatial dynamics of neustonic communities with $\mathrm{Chl}$ a gradients to identify potential oceanographic processes of spatial mesoscale producing aggregation of zooplankton (Garcon et al., 2001) during cruise CIMAR 25 Fjord (C25F, 2019), and compare it with a previous neustonic study carriedout during CIMAR 16 Fjord (C16F, 2010), where aggregation of three taxa (copepodites of Microsetella rosea, larvae of the polychaete Polygordius sp and cyphonautes of the bryozoan Membranipora isabelleana) were studied.

\section{STUDY AREA}

Zooplankton aggregation, hydrographic and remote sensing data were employed to relate the spatial dynamics of neustonic communities with salinity, sea surface temperature (SST), chlorophyll a (Chl $a)$ and suspended organic matter (SOM) at a spatial mesoscale $(10$ to $1000 \mathrm{~km})$ in the southern Chilean fjords system along Magellan Strait, Chile (oceanographic expeditions CIMAR 16: October/November 2010 and CIMAR 25; September/October 2019) in order to identify oceanographic process producing aggregation of neuston. The spatial dynamic of oceanographic parameters in the surface pelagic zone and their relationship with some ecological variables of the neustonic layer were sampled in the area extended between $50^{\circ}$ y $54^{\circ} \mathrm{S}$, Magellan región, Chile (Fig. $1)$.

\footnotetext{
*Corresponding author
} 


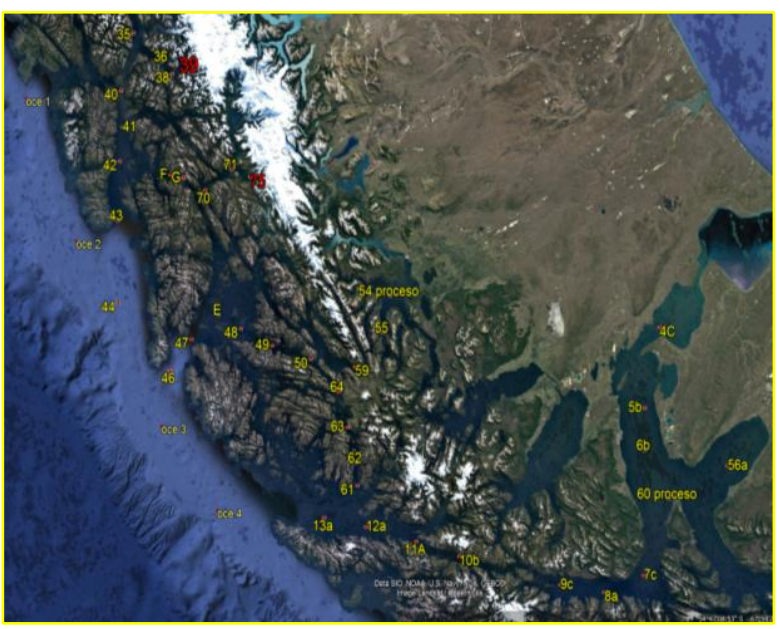

Fig. 1. Study area with oceanographic stations of CIMAR 25 cruise (September/October 2019).

\section{MATERIAL AND METHODS}

During the CIMAR 25 Fjord cruise, sensoring remote analysis was developed to obtain oceanographic and biological data using the following sources of information in the period September/October, 2019:

i) Oceanographic information on surface layer of water column (temperature, chlorophyll $a$ and suspended organic matter) obtained throught differents satelital data base. This information was compared with oceanographic data recorded during CIMAR 16 and CIMAR 25 Fjord performed in Magellan waters.

ii) Wind data recorded onboard of AVG 61 Cabo de Hornos platform during CIMAR 16 \& 25 Fjord.

iii) Oceanographic data in situ were recorded by a Sea Bird thermo-salinometer and vertical profiles of CTDO during CIMAR 16 and 25 Fjords.

iv) Data on neustonic biomass collected during CIMAR 16 (2010) and CIMAR 25 Fjord (2019).

The following information was analysed to describe the oceanographic features of the sea surface waters of Magellan area:

i) Sea surface temperature. Data obatined from Modis Data $11 \mu \mathrm{m}$, including all records of 2019.

ii) Chlorophyll a (Chl a). This information was obtained from HERMES (http://hermes.acri.fr/), Globuscolour (spatial resolution to $4 \mathrm{~km}$ and daily variability in the period October and November 2010 and 2018). This basis of data mixed information of SeaWIFS, MERIS, MODIS $\mathrm{y}$ VIIRS.

iii) Neuston and Identification of mesoscale oceanographic processes (10 a $1000 \mathrm{~km})$ : The Magellan Strait offer an opportunity to study the ocurrence of oceanographic front due to the mix of Atlantic and Pacific Ocean waters, presence of island of different sizes, sill under different micro basins featured by different depths, seamount, freshwater discharge and the interaction between small embayments with the strait. These process could to produce aggregation of zooplankton communities living in surface layers such as the neuston (Garcon et al., 2001).

\section{RESULTS}

In reference to the neuston and the existence of oceanographic process along Magellan Strait, we consider information recorded during CIMAR16 Fjord (C16F, spring 2010), where was reported a significant aggregation de the neuston in the northeastern end of Dawson Island, off Inútil Bay, Magellan Strait (Fig. 2).
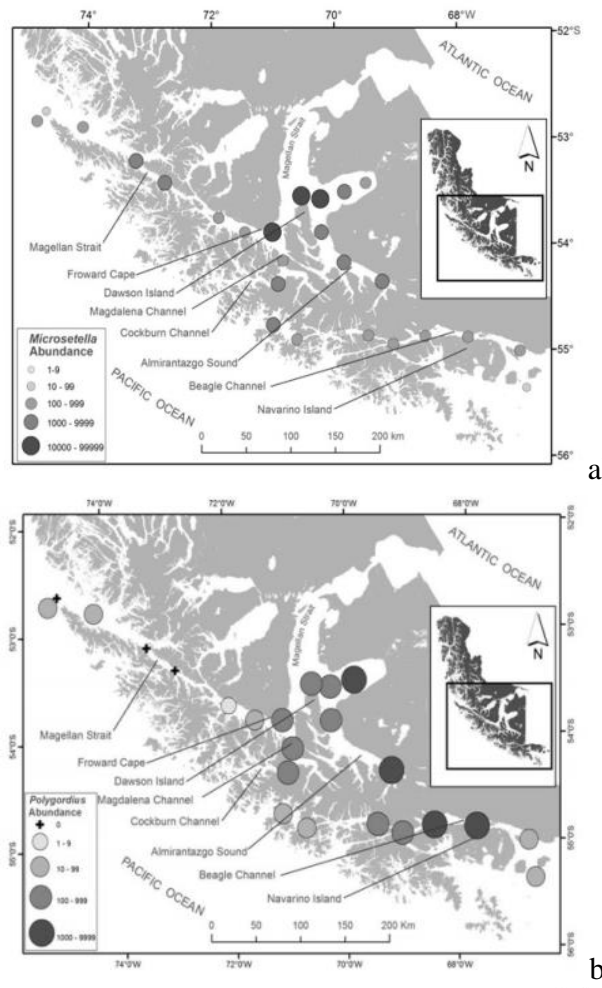

b)

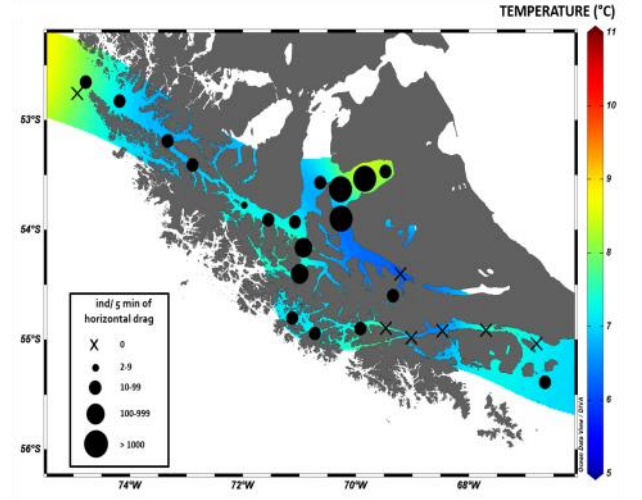

c)

Fig. 2. Spatial distribution of total abundance of three neustonic taxa along Magellan Strait, Chile, during CIMAR 16 cruise (2010): a) copepodites of Microsetella rosea, b) larvae of the polychaete Polygordius sp, c) Cyphonautes of the bryozoan Membranipora isabelleana.

In this area, between 60 and $80 \%$ of the total abundance of three typical neustonic species was estimated: copepodites of pelagic harpacticoid copepod Microsetella rosea, larvae of the polychaete Polygordius sp and cyphonautes larvae of bryozoan Membranipora isabelleana (Cañete et al., 2016, 2019). Such spatial scale correspond to mesoscale (Mann, Lazier, 1991; Cañete et al., 2017). The neuston was collected with a net of $50 \times 35 \mathrm{~cm}$ of mouth area, mesh net of $43 \mu \mathrm{m}$, which was dragged for 5 minutes with a velocity of $2 \mathrm{kn}$ (horizontal drag $=500 \mathrm{~m}^{2}$ ) (Cañete et al., 2016, 2019). This neustonic aggregation is supported by important concentration of chlorophyll $a$ around Dawson Island during sampling of 
CIMAR 16 Fjord (spring 2010) and during spring 2018 (Fig. 3) (http://hermes.acri.fr/).

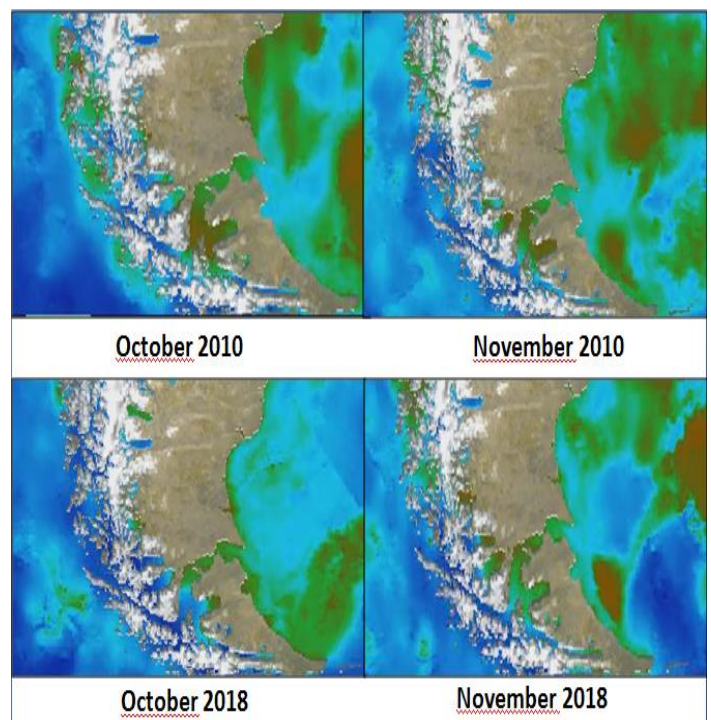

Fig. 3. Surface spatial distribution of Chlorophyll $a$ along Magellan Strait in the spring of 2010 (CIMAR 16) and 2018 (modified of http://hermes.acri.fr/).

Spatial analysis of Chlorophyll $a$ during spring 2019 in the Magellan Strait and around showed that a concentration of 3 $\mathrm{mg} \mathrm{m}^{-3}$ is common around Dawson Island. Similar situation was observed during spring 2010 and 2018 (Fig. 4).

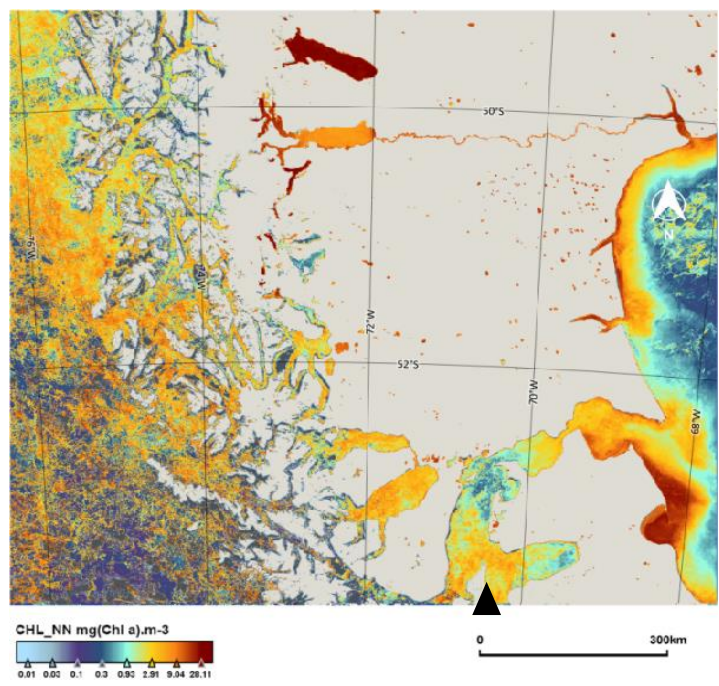

Fig. 4. Spatial distribution of Chlorophyll $a$ and suspended organic matter in the Magellan región and along Magellan Strait during 2019. Black arrow showing Dawson Island. Bar scale: $200 \mathrm{~km}$ (Elaborated by X. Aguilar).

\section{CONCLUSIONS}

The remote sensing in the study area provided evidence to demonstrate that around Dawson Island there are a recurrent aggregation of chlorophyll $a$ and neuston. Topographic front, presence of sill, wake island effect, cyclonic or anticyclonic eddies around island and thermal front between warmest Atlantic water and cold Pacific water near to Dawson Island could to explain this aggregation of neuston.

\begin{tabular}{|c|c|c|c|}
\hline Variables & $\begin{array}{c}\text { Cimar 16 } \\
(2010)\end{array}$ & $\begin{array}{c}\text { Cimar 20 } \\
(2014)\end{array}$ & $\begin{array}{c}\text { Cimar 25 } \\
(2019)\end{array}$ \\
\hline $\begin{array}{c}\text { Temperature } \\
\left({ }^{\circ} \mathrm{C}\right)\end{array}$ & $\begin{array}{c}6.5-8.5 \\
(7.2 \pm 0.6)\end{array}$ & $\begin{array}{c}6.8-10.7 \\
(9.3 \pm 0.8)\end{array}$ & $(7.3 \pm 0.8)$ \\
\hline $\begin{array}{c}\text { Salinity } \\
(\mathrm{psu})\end{array}$ & $\begin{array}{c}26.0-33.0 \\
(30.5 \pm 1.3)\end{array}$ & $\begin{array}{c}1.0-31.7 \\
(23.3 \pm \\
7.5)\end{array}$ & $(28.7 \pm 3.8)$ \\
\hline $\begin{array}{c}\text { Oxygen } \\
\left(\mathrm{mL} \mathrm{O} \mathrm{L}^{-1}\right)\end{array}$ & $\begin{array}{c}4.0-10.0 \\
(7.4 \pm 0.4)\end{array}$ & $\begin{array}{c}6.7-8.5 \\
(7.5 \pm 0.5)\end{array}$ & w.i. \\
\hline
\end{tabular}

Table 1. Main oceanographic features of three estuaries areas of the southern Chilean coast considered to analyze the

biodiversity and composition of the neustonic communities in channels and fjords. In brackets is showed the mean and standard deviation for each oceanographic parameter; w.i.: without information.

However, these levels of chlorophyll $a$ is typical of a mesotrophic condition. Microbasin where is located Dawson Island is dominated by traditional trophic web sustained by phytoplankton to difference to other two microbasin of the Magellan Strait where microbial trophic web dominate (Antezana, 1999; Hamamé \& Antezana, 1999). The three cruises shows typical oceanographic values of the Magellan chnnel/fjord system (Table 1), where prevails high concentration of dissolved oxygen, estuarine conditions with low salinities near to river and fjords, increasing from east to west. The average temperature is coincident with previous values recordad by differents studies (Dávila et al., 2002; Silva, Palma, 2008; Pantoja et al., 2011; Iriarte et al., 2014; Cañete et al., 2016).

Remote sensing in this study area provides a tool to understanding oceanographic and topographic factors that potentially regulate the abundance and spatial distribution of surface zooplankton along Magellan Strait.

\section{ACKNOWLEDGEMENTS}

The first author thanks to Chilean Navy for financial support of grants Cimar 16, 18, 20 and 25 to study the neuston from southern Chile. Special thanks to the crew of Abate Molina and AVG 61 Cabo de Hornos for assistanship during sampling campaigns.

\section{REFERENCES}

Antezana T. 1999: Hydrographic features of Magellan and Fuegian inland passages and adjacent Subantarctic waters. Sci. Mar., 69 (Suppl. 1): 23-34.

Cañete, J. I., Gallardo C., Olave, C., Romero, M.S., Figueroa, T., Haro, D. 2016: Abundance and spatial distribution of neustonic copepodites of Microsetella rosea (Harpacticoida: Ectinosomatidae) along the western coast of Magellan, southern Chile. Lat. Am. J. Aq. Res. 43: 576-587.

Cañete, J. I., Díaz-Ochoa, J. A., Figueroa, T., Medina, A. 2017: Infestation of Pseudione tuberculata (Isopoda: Bopyridae) on juveniles of Lithodes santolla (Region of Magallanes, Chile): a spatial mesoscale analysis. Latin American Journal of Aquatic Research, 45, 79-93.

Cañete, J.I., Gallardo, C.S., Medina, A., Díaz-Ochoa, J., Olave, C., Figueroa, T., 2019: Abundance and spatial distribution of Polygordius (Polychaeta:Polygordiidae) neustonic exolarvae in estuaries from southern Chile. Anales Instituto Patagonia 47: 19-33. 
Dávila, P.M., Figueroa, D., Müller, E., 2002: Freshwater input into the coastal ocean and its relation with the salinity distribution Off austral Chile $\left(35-55^{\circ} \mathrm{S}\right)$. Continental Shelf Research 22: 521-534.

Garçon, V., Oschlies, A., Doney, S., McGillicuddy, D, Waniek, J., 2001: The role of mesoscale variability on plankton dynamics. Deep Sea Research, Part II, 48: 2199 2226.

Hamamé, M., Antezana, T., 1999: Chlorophyll and zooplankton in micro basins along the Magellan Strait-Beagle Channel passage. Scientia Marina 63 (Supl.1): 35-42.

Hardy, J.T. 1991: Where the sea meets the sky. The ocean's skin is the richest, most extensive habitat of all. Natural History, American Museum of Natural History, pp. 1-3.

Hardy, J.T. 2005. Biological effects of chemicals in the seasurface micro layer. In: P.S. Liss \& R.A. Duce (eds.). The sea surface and global change, Cambridge University Press, pp. 339-370.

Hays, G.C., Richardson, A.J. Robinson, C. 2005: Climate change and marine plankton. Trends in Ecology and Evolution 20: $337-344$.
Iriarte, J. L., Pantoja, S., Daneri, G., 2014: Oceanographic processes in Chilean fjords of Patagonia: from small to largescale studies. Progress in Oceanography 129: 1-7.

Mann, K.H., Lazier, J. R., 1991: Dynamics of marine ecosystems: Biological-physical interactions in the oceans. Blackwell, Malden, Massachusetts, 466 pp.

Palma, S, Córdova, P., Silva, N., Silva, C., 2014: Biodiversity and spatial distribution of medusae in the Magellan Region (Southern Patagonian Zone). Latin American Journal of Aquatic Research 42: 1175-1188.

Pantoja, S., Iriarte, J.I., Daneri, G., 2011: Oceanography of the Chilean Patagonia. Continental Shelf Research, 31: 149-153.

Silva, N., Palma, S. (editors), 2008: Progress in the oceanographic knowledge of Chilean interior waters, from Puerto Montt to Cape Horn. Escuela de Ciencias del Mar, Pontificia Universidad Católica de Valparaíso.

Valdenegro, A., Silva, N., 2003: Caracterización oceanográfica física y química de la zona de canales y fiordos australes de Chile entre el estrecho de Magallanes y cabo de Hornos (Cimar 3 Fiordos). Ciencia y Tecnología del Mar, CONA, 26: 19-60.

Zaitsev, Y. 2005: Neuston of seas and Oceans. In: Peter S. Liss \& R.A. Duce (eds.), The sea surface and global change. Cambridge University Press, pp. 371-382. 